日消外会誌 $19(8): 1801 \sim 1805,1986$ 年

卒後教育セミナー 4

胸部食道癌の手術：術後の管理対策（概説）

\author{
東海大学第 2 外科 \\ 三 富 利 夫
}

\title{
SURGERY OF THE THORACIC ESOPHAGUS PERIOPERATIVE MANAGEMENT
}

\section{Toshio MITOMI}

Dept. of Surg. School of Med. Tokai Univ.

索引用語 : 胸部食道癌, 食道癌術後管理, 食道癌術後合併症

はじめに

胸部食道癌の治療は近年大さな進歩をみせている が，進行癌の占める割合がいまだに明らかに改善され たといえない状況にあっては，患者側にとって内容的 に䈌しい多くの因子が加わりつつある所である，歴史 的には少なかった胸部食道癌の手術を行う施設が近年 にいたって非常に多くなり,年間 5,000 人といわれる食 道癌患者の5ち手術的治療対象が 5 分の 1 に及ばない といら状態の改善に役立っている. 手術成績面では, いわゆる“周術期”, 術前, 術中, 術後にわたる管理面 の改善, 術後合併症に対する積極的な治療法の進歩が 効果を発揮し, 成績を向上し, 手術も汪とんどの症例 が一期的に行われ，治療計画が遂行されるようになっ た.しかし，胸部食道癌の遠隔治療成績の実態はまだ 不充分であるため, 限界とされていた郭清術式をより 根治的に拡大する試みが導入され，また，集学的な療 治療プログラムの開発が急務とされる段階にある。

\section{術後合併症}

胸部食道癌切除再建術後の術後合併症の発生は, 何 らかの異常を来したものすべてをあげると極めて高率 である(表 1 ). 年代的には術後合併症の発生が高率で, かつ予後不良であった昭和30〜40年代に比べて病態の 解析, 管理対策の進歩を基盤に最近の手術成績は著る しく改善した。とくに呼吸循環系などのモニタリング および管理機器, 経中心静脈高カロリ一輸液 (TPN) あるいはェレメンタル・ダイェット（ED）による栄養 法の発達はむずかしい手術, 合併症の管理を可能とし

第 8 回卒後教育セミナー・胸部食道癌の手術 $<1986$ 年 5 月 14 日受理 $>$ 別刷請求先：三富 利夫 T289-11 伊勢原市望星台 東海大学医学部第 2 外科
表 1 術後合併症発生率

\begin{tabular}{lcl}
\hline 胸部食道癌切除例 & 150 例 & \\
術後合併症発生例 & 109 & $72.7 \%$ \\
呼吸器系 & 58 & 38.7 \\
(肺・気管支・気管 & 35 & 23.3 \\
胸腔・縌隔 & 30 & 20.0 \\
循環系 & 17 & 11.3 \\
吻合部・創関連 & 51 & 34.0 \\
神経系 & 36 & 24.0 \\
代謝系 & 50 & 33.3 \\
その他 & 5 & 3.3 \\
\hline
\end{tabular}

(東海大外科)

た。その結果，より高齢者を含めた機能的手術適応限 界の拡大, 病巣に対する他藏器合併切除, るとから問 題とされていた上縦隔, 非開胸側を中心とするリンパ 節郭清の徹底などが行われるようになり, 術後合併症 も多彩で, 従来と異なるものが加わることになった(表 2)。また，遠隔成績が不良の群を中心とした症例には 集学的癌治療の導入, とくに多剤抗がん剤療法の手術 前あるいは後の適用は患者の病態を一層複雑にしてい る.

一方, “周術期”に和けるモニタリングの進歩は, 情 報提供を速かで，豊富にしたために，術後機能状態の 評価, 術後合併症診断の精度が高められたことから, 術後管理対策は, より細かく, 速く評価, 診断して, より積極的な対応を図る方向にあるとい方よう。表 3 は術後呼吸器系合併症の10年間における推移である が，前述した治療方針の変遷を反影するようで, 術後 合併症の発生が減少する傾向がなく, から, 後記する 気道の阻血のような特殊な合併症が死亡につながった 
表 2 術後合併症

\begin{tabular}{|c|c|c|c|c|}
\hline \multicolumn{5}{|c|}{ 胸部食道癌切除例 150 例 東海大外科 } \\
\hline \multicolumn{3}{|l|}{ 肺・気管支・気管 } & \multicolumn{2}{|l|}{ 昒合部・創関連 } \\
\hline 無気肺 & 17 & $11.3 \%$ & 縫合不全 & $3322.0 \%$ \\
\hline 肺炎 & 11 & 7.3 & 再建蔵器壊死 & $4 \quad 2.7$ \\
\hline 無下性肺炎 & 5 & 3.3 & 吻合部狭窄 & 1510.0 \\
\hline 肺水腫 & 1 & 0.7 & 創感染 & $8 \quad 5.3$ \\
\hline ARDS & 1 & 0.7 & 創哆開 & $\begin{array}{ll}1 & 0.7\end{array}$ \\
\hline 気管・気管支阻血 & 4 & 2.7 & 腰膜炎 & 10.7 \\
\hline 肺膿瘍 & 1 & 0.7 & 骨䯣炎 & 10.7 \\
\hline \multicolumn{3}{|l|}{ 胸腔・縦隔 } & \multicolumn{2}{|l|}{ 神経系 } \\
\hline 胸水貯留 & 13 & 8.7 & 反回神経麻疩 & 3624.1 \\
\hline 気胸 & 5 & 3.3 & 迷走神経麻瘒 & $\begin{array}{ll}1 & 0.7\end{array}$ \\
\hline 血胸・後出血 & 6 & 4.0 & 肋間神経痛 & 10.7 \\
\hline 乳糜胸 & 3 & 2.0 & 精神障害 & 10.7 \\
\hline 膿胸 & 2 & 1.3 & 代謝系 & \\
\hline 縦隔炎 & 1 & 0.7 & 肝障害(低下) & 4932.7 \\
\hline \multicolumn{3}{|l|}{ 循環学 } & 急性腎不全 & 10.7 \\
\hline 不整脈・頻脈 & 14 & 9.3 & HHNK & $2 \quad 1.3$ \\
\hline 心原性ショック & 4 & 2.7 & その他 & \\
\hline \multirow[t]{4}{*}{ 心筋梗塞 } & 1 & 0.7 & 腸閉塞 & 10.7 \\
\hline & & & 血栓静脈炎 & 21.3 \\
\hline & & & ほか & $2 \quad 1.3$ \\
\hline & & & \multicolumn{2}{|c|}{ （症例は重複して集計） } \\
\hline
\end{tabular}

表 3 術後呼吸器系合併症, 年次推移

\begin{tabular}{l|c|c|c}
\hline & $1975 \sim 1978$ & $1979 \sim 1982$ & $1983 \sim 1985$ \\
\hline 胸部食道癌切除例 & 46 & 50 & 54 \\
合併症発生例 & 16 & 17 & 23 \\
$\quad$ " 発生率 & $34.8 \%$ & $34.0 \%$ & $42 \%$ \\
合併症による死亡例 & 5 & 0 & 3 \\
\hline
\end{tabular}

結果を示している。

術後の管理対策としては“周術期=perioperative” の管理として捉えるべきものであるから, 術前, 術中 管理の要点す含めて概説する。術後早期の呼吸・循環 管理については別項にゆずる。

\section{術前管理（表 4 ）}

1. 検查

1) 病巣に関するすの

主病巣の確定診断ならぴに深達度診断 ( $\mathrm{T})$ が手術の 大きさをほほ決定するが, 最近では CT, 超音波, 超音 波内視鏡, 血管造影, シンチグラムなどにより $\mathrm{Nx}, \mathrm{Mx}$ としたるのの評価も可能で, 術式選択の決定に対して 意義が高い12).

2）一般全身状態に関するすの

i ）バイタルサイン, 体液平衡的なるの

ii）一般血液, 生化学
表 4 術前管理

\begin{tabular}{|c|c|}
\hline 1) 病巣㟝断 & $\begin{array}{l}\text { 食道造影，内視鏡，生检，超音波， } \\
\text { CTスキャン，血管造影 }\end{array}$ \\
\hline 2）一般状態 & (1) バイタル・体液平衙 \\
\hline 関する & (2) 一般血㖡·生化学 \\
\hline ఈの & 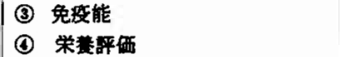 \\
\hline 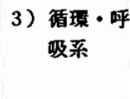 & 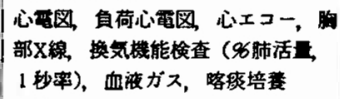 \\
\hline $\begin{array}{l}\text { 4）肝・霄・ } \\
\text { 耐糖能 }\end{array}$ & 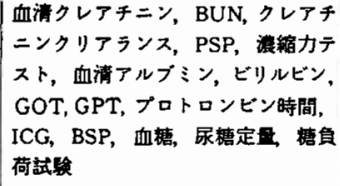 \\
\hline
\end{tabular}

術前・対策と処置

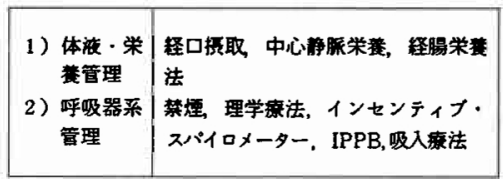

iii）免疫能，腫蕩関連抗原ほか

担癌状態, 高齢では免疫系の变化があって, 免疫監 視機構の機能異常としてとらえられ, 癌の状態, 感染 症などとの関連が高いので, 検索範囲はともかく, 術 前後を通したモニターとして必要であり，集学的治療 の指標としても考壳たいるのである.

iv) 栄養評価

生体を評価する上で基本となるものであるから，栄 養評価指数（NAI）を計算するために必要な身体計測 値 $(\mathrm{AC} な と ゙)$, 栄盖摂取平衡の記録, 血液, 尿化学 $(\mathrm{T}$. P., PA, RBPなど)をチェックして置く必要がある。

3）循環機能に関するもの

心疾患とくに心筋梗塞の既往のある患者が増加して いるが，一般的には $3 \sim 6$ 力月の安定期間を目途とし て手術適応が考えられて来た。最近ではわが国です心 筋梗塞患者の評価，管理が変って来て批り，Cardiac Risk Index（Goldman, L)などを参考にして，発作か ら比較的早い時期（1 2 カ月）でも Tredmill 試験, 心シンチ，超音波，CAGなぞを行って判断したい，将 来はペースメーカーの準備だけでなく，A-Cバイバス あるいは大動脈バルーンパンピングの準備も含めて対 応することが必要な時代になることも考えられる。

4）呼吸機能関するるの

所見があるものに対しては循環器系と同様に早くに 機能検査をすませて，評価と対策をとりたい，

5）肝，腎，耐糖能はか 
術前から集学的癌治療, 中心静脈栄養の適用が始ま る症例に対しても，早い時期に調べておく。

2. 必要な対策・処置

1）体液，栄養状態の是正

経口摂取障害がある場合だけでなく，集学的治療計 画に沿って，予測をふくめて積極的に管理したい。

2) 呼吸器系の管理

禁煙は出来るだけ早くに徹底させ，理学療法，呼吸 訓練など専任者による体制が望ましい。

3）心，肺，その他の合併疾患のある場合

治療対策は計画的にタイミングを考党てなさらなけ ればならない、高龄の心機能障害例では肺機能やその 他の障害む多く, 細かい術前管理と評価が必要で, 手 術侵襲の軽減を可及的に図りたい。

\section{術中管理}

1. 術中検査ならびにモニタリング

実際には麻酔医によって行われるものであるが，術 野を含めた患者の綜括的な管理の任は術者側にあるこ とを常に念頭に置かなければならない，患者情報は確 夹に経時的に把握されなければならないし，とくに体 位変換などの段階では注意，確認することで，さらに 術後へと継続する（表 5 ）.

2. 必要な対策, 処置

1) 開胸時の肺虚脱

開胸側の虚脱された肺は定時的に加圧して再膨脹と 気道内浄化を図るが，最近，われわれは可動性ブロッ カー付気管内チューブによる片肺換気を試み，良好な 術野, 手術操作の容易, 安全性の面で有用性を認めて いる (写真 1$)^{3)}$.

2）手術終了時のチェックポイント
表 5 患者監視のための一般的なモニタリング

\begin{tabular}{|c|c|c|}
\hline & 项 & 正常偖 \\
\hline & 坋脈孟压 & $120 / 80 \mathrm{mmHg}(\bar{m} 92 \pm 5 \mathrm{mmHg})$ \\
\hline 2) & 㭛拍政 & 70 \\
\hline 3) & 中心静脈圧 & $5-10 \mathrm{mH}_{3} \mathrm{O}$ \\
\hline 4) & 胡動㟲厓 & $13 \pm 1 \mathrm{mmHg}(\overline{\mathrm{m}})$ \\
\hline 5) & 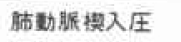 & $5 \pm 2 \mathrm{mmHg}(\overline{\mathrm{m}})$ \\
\hline 6) & 心拍出量 & $4 \sim 7 \mathrm{l} / \mathrm{min}$ \\
\hline 7) & 末梢血管抵抗 & $2180 \pm 21$ odyne $-\mathrm{sec} / \mathrm{cm}^{\mathrm{s}} / \mathrm{M}^{2}$ \\
\hline 8) & 瑚血管抵抗 & $135 \pm$ 45dyne-sec $/ \mathrm{om}^{5} / \mathrm{M}^{2}$ \\
\hline 9) & 心保数 & $3.2 \pm 0.2 \ell / \mathrm{min} / \mathrm{M}^{2}$ \\
\hline 10) & 略間尿量 & 30 50 $\mathrm{m} / \mathrm{hr}$ (期待俌 $)$ \\
\hline 11) & 尿此重 & $1.003-1.025$ (期待伹) \\
\hline 12) & 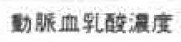 & $5-18 m_{q} / 100=l$ \\
\hline
\end{tabular}

写真 1 ュニベントチューブ 上：気管支ブロッカー,下：気管内チューブ

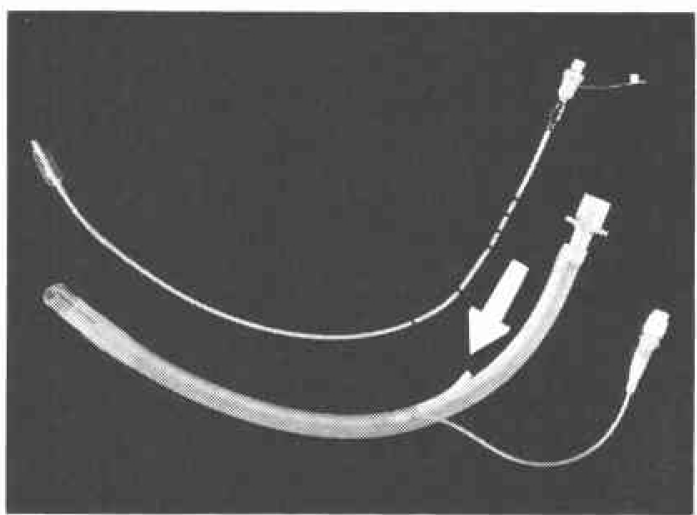

表 6 術後管理対策

\begin{tabular}{|c|c|c|}
\hline 2）循環 - 呼吸系管理 & $\begin{array}{l}\text { (1) バイタルサイン } \\
\text { (2) 検査 } \\
\text { (1) モニタリング } \\
\text { (2) 呼吸 }\end{array}$ & $\begin{array}{l}\text { 血圧, 脈, 体温, 呼吸数, 尿量 } \\
\text { 末梢血, 血液生化学, 血液ガス, 尿定性 } \\
\text { 尿比重, 胸部X線 } \\
\text { (別項) } \\
\text { 調節呼吸, IPPB, ネプライザー } \\
\text { 体位変換, 早期離床 } \\
\text { インセンティブ・スパイロメーター } \\
\text { 気管支ファイハースンープ }\end{array}$ \\
\hline 3）ドレーン管理 & \multirow{3}{*}{\multicolumn{2}{|c|}{ 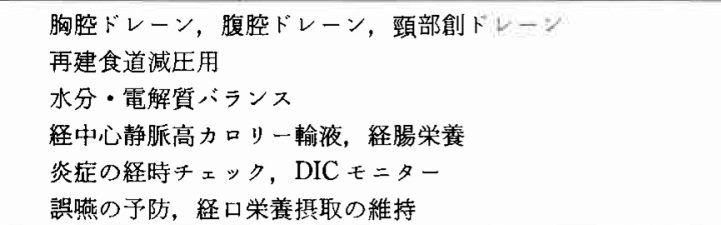 }} \\
\hline 4）体液・栄養管理 & & \\
\hline $\begin{array}{l}\text { 5）創・吻合部感染 } \\
\text { 6) 喀痰, 嗄声 }\end{array}$ & & \\
\hline
\end{tabular}


i ）患者状態に関して

換気状態とくに両側開胸，対側肺虚脱，対側胸腔内 液貯溜に注意する。

胸管損傷，臓側胸膜損傷に対しては処置を確認し， 出血と輸血のバランスも確かめる.

気道内清浄化はかならず行い, 出来れば気管支ファ イバースコープにより処置したい.

ii ) ドレーンなど

胸空ドレーンについては接合, 吸引圧, 量, エアー リークの有無，概量をみる，経鼻胃管，胃瘻，晹㾞な ぞがある場合は，位置，固定を確かめ，内腔の洗涤か 水を通して置くとよい，頸部拈よび腹部ドレーンにつ いては胸腔との異常な交通がないことを確認する。

\section{術後管理 (表 6)}

1. 検査・モニタリング・シートの作成

1）一般全身状態関して

i ）バイタルサイン，尿

ii）一般血液, 生化学, 血液ガス

iii）胸部 X 線

2）循環・呼吸系モニタリング（別項）

3）ドレーン，カテーテルの排液管理

4) 体液平衡

5）栄養管理

2. 必要な対策・処置

検査およびモニタリングから得られた情報をもとに
管理行らが，わかりやすい記録整理がのぞまれる，術 後合併症に対してはまず予防策であり，異常に対して は早期の治療対策をとることが基本である4).

1）胸腔ドレーン 多くの情報が胸腔ドレーンから 得られるので，有効に維持されることが重要である. 術式の拡大から術後早期の後出血，あるいは乳瘦胸の 発生などの可能性があり，確実な情報とこれらの病態 が念頭にあれば診断はつけやすい。エアーリークによ る排気量が多い場合は胸腔内圧の变動をみて適正な吸 引が得られる装置またはビューロ型式に変更すること もあるので，低圧持続吸引器の性能を知って置く必要 がある.

2) 呼吸系

3) 循環器 (輸血・輸液) \}別項

4）創・吻合部管理

消化管吻合部の縫合不全は現在でも頻度の高い合併 症である. 早期の縫合不全は術後 $4 \sim 5$ 日目に, 遅発 性のものは 9 14日頃に発生するが, 再建荗器の血行 障害を伴って吻合部付近の穿孔，壊死を来すものはよ り早期で症状も重篤である。一般には感染巣を生じた ら限局化，巣のドレナージ，不全部消化管内腔の減圧 と内容の除去を図り，から体液と栄養の維持が治療の 基本である。一般には極めて限局した部分的膿瘍であ ることが多く，ドレナージの判断は慎重を要する。

5）感染全般の管理

表 7 胸部食道癌術後気管気管支阻血症例

\begin{tabular}{|c|c|c|c|c|c|c|c|c|}
\hline 症例 & $\begin{array}{l}\text { 年令 } \\
\text { 性 }\end{array}$ & 型 & 進 行 度 & 術 & 術後合倒症 & $\begin{array}{l}\text { 気管棲死 } \\
\text { 発現期間 }\end{array}$ & 分 & 枟 \\
\hline 1 & $\begin{array}{l}75 \\
\text { 男 }\end{array}$ & $\begin{array}{l}\text { Ei } 4.5 \mathrm{~cm} \\
\text { 漏 } 4 \text { 型 }\end{array}$ & $\begin{array}{l}\text { MoPlon }_{2} \mathrm{a}_{2} \\
\text { stage III }\end{array}$ & $\begin{array}{l}\text { 右開胸開腋胸部 } \\
\text { 道 全 摘 } \\
\text { 胸壁前頻部食道 } \\
\text { 管吻 合 術 }\end{array}$ & $\begin{array}{l}\text { 券上胃管壞死 } \\
\text { 術後 } 3 \text { 日目 }\end{array}$ & 術後 2 日目 & & 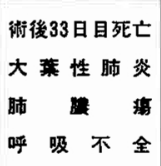 \\
\hline 2 & $\begin{array}{l}64 \\
\text { 男 }\end{array}$ & $\begin{array}{l}\text { ImEi } 7.5 \mathrm{~cm} \\
\text { ラセン 型 }\end{array}$ & $\begin{array}{l}\text { MoPlon } a_{3} \\
\text { (左主気管支) } \\
\text { stage IV }\end{array}$ & 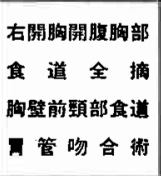 & $\begin{array}{l}\text { 粪上胃管㙲死 } \\
\text { 術後 } 2 \text { 日目 }\end{array}$ & 術挠 3 日目 & & 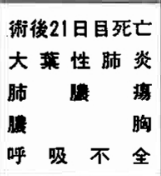 \\
\hline 3 & $\begin{array}{l}62 \\
\text { 男 }\end{array}$ & $\begin{array}{l}\operatorname{lmEi} 7.5 \mathrm{~cm} \\
\text { 鋸 型 }\end{array}$ & $\begin{array}{l}\text { MoPlon }_{2} \mathrm{a}_{0} \\
\text { stage III }\end{array}$ & 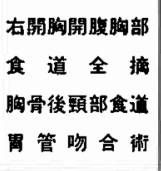 & 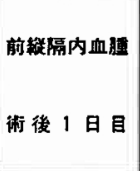 & 術後 1日目 & 냉 & 生 \\
\hline 4 & 61 & $\begin{array}{l}\text { luCe } 7.0 \mathrm{~cm} \\
\text { 鋸 型 }\end{array}$ & $\begin{array}{l}\text { MoPlon }_{2} a_{1} \\
\text { stage III }\end{array}$ & $\begin{array}{l}\text { 右開胸開腹胸部 } \\
\text { 食 道 全 摘 } \\
\text { 胸壁前頚部食道 } \\
\text { 管吻 合 術 }\end{array}$ & & 術後 1 日目 & 3 & 生 \\
\hline
\end{tabular}


担癌で高齢という感染に弱い傾向があるので, 臨床 症状の程度より病態の重症度が見かけより高いものが ある. 感染症の進行は複数臓器障害に追いこまれやす く, DIC の発生をモニター（血小板，FDPなど）して 早期の対応を常に考党て置いた方がよい。

6）特殊な状態に対する管理

i）嗄声の管理 縦隔リンパ節の扗大郭清により嗄 声の発生が術後早期に高率であるが, 一過性で回復経 過をとるものが少くない，かなりの期間は誤嚥しゃす いため，経口摂取は可及的に慎重にゆっくり開始し， 反回神経麻疩が持続するものに対しては, シリコンの 声帯内注入による固定法で機能的に改善が得られる。

ii ) 気道系の阻血性变化 食道癌の上粉隔郭清例で は気管・気管支の血行が低下する傾向があったり，気 道内容の排泄能中咳嫩反射などが不良となることが指 摘されているが，われわれは従来認めなかった気管・ 気管支の阻血性変化を来した症例を経験した。術中操 作から術後の喀痰吸引まで全てに愛護的に取り扱うべ きであるが，一部気管支動脈系の温存も対策の一つと 考光，広範郭清例に試みている(表 7).

iii）乳糜胸，呼吸循環系に影響が急激に現われるよ うな乳糜胸には重篤な経過をとるものがあり, 早い診 断, 治療が重要である. 全身状態が悪化する前に治療 対策を判断しなけれぱならないが，肝硬変合併例では 胸管流量が大量の場合もあること，栄養のみでなくリ ンパ球系の消耗を招くことなどなども考慮する，基本 的には的確な排液, 循環血浆量と栄養の維持, positive end-expiratory pressure (PEEP) などの換気補助に よる呼吸管理により自然治㦄を図るのが原則で, 手術 適応は重篤な症状を呈するもの, 排液が多量かつ持続
して管理困難なものなどにたてるが判断は症例個々に よることになる5).

iv）吻合部狭窄 胸部食道の再建術後では縫合不全 を生じたものでなくとも吻合狭窄あるいは通過不良と なることが少なくない，充分な経口摄取は患者の performance state 著明に恢復させ，術後の治療計画の 遂行に必須である。通常は mercury bougie(歎性で水 銀が充媜されたもの）で后とんどの症例に有効な払張 が得られる. 高度の狭窄例に対しては内視鏡下にガイ ドワイヤーを挿入し，バルーン付拡張器あるいは狭窄 部切開を行らがまれである。

\section{むすび}

胸部食道癌の術後管理ならびに術後合併症の対策に ついて概説したが，治療対象およびその内容はきびし くなる傾向があり，かつそれに伴う種々の病態も加わ るので, 注意深い対応が治療の充実, 成績の向上につ ながるすのである.

\section{文 献}

1) 森昌造, 石田 薏, 岡本和美ほか：変わりゆく手 術適応と手術手技一食道癌。外科 $47: 1127$ $-1132,1985$

2）三富利夫, 幕内博康, 生越喬二ほか：早期食道癌の 治療. 外科診療 $53: 587-591,1985$

3）杉原隆, 幕内博康, 佐々木哲二注か：胸部食道手 術に括ける片肺換気一可動性ブロッカー付気管内 チニーブの使用経験. 日消外会誌 $18: 1595$ $-1599,1985$

4）佐藤 博, 磯野可一, 小野田昌一：食併症管理、 $=ュ$ アル胸部食道癌手術. 消外 $8: 764-765$, 1985

5）三富利夫, 野登 隆, 中䐀久雄: 合併症管理 $ニ=$ アル乳糜胸。消外 $8: 914-915,1985$ 